\title{
PENGARUH MODEL PBL TERHADAP HASIL BELAJAR SISWA PADA PEMBELAJARAN PENDIDIKAN KEWARGANEGARAAN KELAS V SEKOLAH DASAR
}

\author{
Oleh: Adela \\ Oktaviani Dra. \\ Reinita, M.Pd \\ Drs. Zainal Abidin, M.Pd \\ adelaoktaviani26@gmail.com \\ reinita_reinita@yahoo.com \\ zainal_awp@yahoo.co.id
}

\begin{abstract}
Abstrak
Tujuan penelitian yaitu untuk mengetahui pengaruh model PBL terhadap hasil belajar siswa pada Pembelajaran PKn kelas V SDN 09 Bandar Buat. Jenis penelitian adalah eksperimen semudalam bentuk nonequivalent control group design. Populasi dalam penelitianadalah seluruh siswa di kelas V dengan sampel kelas VA sebagai kelas kontrol dan VB sebagai kelas eksperimen. Hasil penelitian menunjukkan yaitu terdapat pengaruh model PBL terhadap hasil belajar siswa pada Pembelajaran PKn kelas V SDN 09 Bandar Buat. Berdasarkannilai thitung sebesar-2.488 dengan P-Value sebesar 0.016. Nilai P-Value lebih kecil dari $\alpha=0.05$ sehingga $\mathrm{H}_{1}$ diterima.
\end{abstract}

Kata Kunci : model pbl, hasil belajar

\begin{abstract}
The purpose of this research is to know the effects of using problem based learning toward student learning result of the civic subject for 5th grade students at SDN Bandar Buat. This is a quasi experiment research with non equivalent control group. The population of the research is all 5th grade students of SDN 09 Bandar Buat with class V/A as the treatment class and class V/B as the control class. The research result shows that there is an effect of using PBL model toward students' learning result of the civic subject for 5th grade students at SDN 09 Bandar Buat. The test result show that 2.488 with P-value 0,016 . So, the value achieved is less than $\alpha=0.05$. It means that $\mathrm{H} 1$ is approved.
\end{abstract}

Keywords: pbl model, learning outcomes 


\section{PENDAHULUAN}

Model Problem Bassed Learning (PBL)adalah model pembelajaran dengan pendekatan pembelajaran siswa pada masalah autentik sehingga siswa dapat menyusun pengetahuannya sendiri, menumbuhkembangkan keterampilan yang lebih tinggi dan inquiry, memandirikan siswa dan meningkatkan kepercayaan diri sendiri. Hosnan (2014:295). "Model Problem Based Learning (PBL) adalah suatu model pembelajaran yang kegiatan pembelajarannya dipusatkan pada tugas-tugas atau permasalahan seharihari, relevan dan dipresentasikan dalam satu konteks".

Model ini bercirikan penggunaan masalah kehidupan nyata sebagai sesuatu yang harus dipelajari siswa untuk melatih dan meningkatkan keterampilan berpikir kritis dan pemecahan masalah serta mendapatkan pengetahuan konsep-konsep penting dimana tugas guru harus memfokuskan diri untuk membantu siswa mencapai keterampilan mengarahkan diri. Pembelajaran berbasis masalah, penggunaannya didalam tingkat berpikir lebih tinggi, dalam situasi berorientasi pada masalah, termasuk bagaimana belajar.

Sani (2014:127) mengemukakan "Problem Based Learning merupakan pembelajaran yang penyampaiannya dilakukan dengan cara menyajikan suatu permasalahan, mengajukan pertanyaan-pertanyaan, memfasilitasi penyelidikan dan membuka dialog. Permasalahan yang dikaji hendaknya merupakan permasalahan kontekstual yang ditemukan oleh siswa dalam kehidupan sehari-hari”. Sejalan dengan itu Riyanto (2010:284) mengemukakan "Problem Based Learning adalah suatu model pembelajaran yang menuntut siswa untuk berfikir kritis, memecahkan masalah, belajar secara mandiri, dan menuntut keterampilan berpartisipasi dalam tim. Proses pemecahan masalah dilakukan secara kolaborasi dan disesuaikan dengan kehidupan”.

Tujuan model PBL adalah menjadikan siswa lebih aktif karena siswa diberi kesempatan mengembangkan kemampuan berfikir, pemecahan masalah, keterampilan belajar, keterampilan memaknai informasi,keterampilan berfikir reflektif, evaluatif, kolaboratif dan belajar tim, serta keterampilan intelektual didalam proses pembelajaran. Sebagaimana tujuan PBL menurut Rusman (2011:238) yaitu "Penguasaan isi belajar dari disiplin heuristik dan pengembangan keterampilan pemecahan masalah sekaligus mengembangkan kemampuan siswa untuk secara aktif membangun pengetahuan sendiri”. 
PBL juga memiliki keunggulan diantaranya membuat siswa kreatif dalam memecahkan masalah sesuai dengan pendapat Trianto (2011:96) “(1) Realistik dengan kehidupan siswa, (2) konsep sesuai dengan kebutuhan siswa, (3) memupuk sikap inkuiri, (4) retensi konsep jadi kuat, (5) memupuk kemampuan memecahkan masalah".

Model PBL dapat digunakan pada mata pelajaran PKn, Pendidikan Kewarganegaraan merupakan mata pelajaran dengan visi utama sebagai pendidikan demokrasi. Namun yang paling menonjol adalah sebagai pendidikan nilai dan pendidikan moral. Oleh karena itu secara singkat Pendidikan Kewarganegaraan dinilai sebagai mata pelajaran yang mengusung misi pendidikan nilaidan moral.

Sistem Pendidikan Nasional di setiap jenis, jalur dan jenjang pendidikan wajib memuat Pendidikan Kewarganegaraan (PKn). Menurut Daryono (2011:1) PKn adalah nama dari suatu mata pelajaran yang terdapat dalam kurikulum sekolah. PKn berusaha membina perkembangan moral anak didik sesuai dengan nilai-nilai Pancasila, agar dapat mencapai perkembangan secara optimal dan dapat mewujudkan dalam kehidupannya sehari-hari.

Pembelajaran PKn merupakan salah satu mata pelajaran yang memiliki peranan yang sangat penting dalam meningkatkan kualitas pendidikan. PKn diajarkan di sekolah dasar (SD) agar siswa menjadi warga negara yang sesuai dengan Pancasila dan UUD 1945 yang dapat memahami dan mampu melaksanakan hak-hak serta kewajiban untuk menjadi warga negara Indonesia yang bertanggung jawab.Oleh sebab itu, dalam pembelajaran PKn di SD siswa harus dilakukan dengan pembelaran-pembelajarn yang inovatif agar dapat meningkatkan pemahaman konsep PKn sehingga berpengaruh terhadap proses dan hasil belajar siswa dan pengimplementasiannya.

Berdasarkan hasil observasi yang peneliti laksanakan pada tanggal 8 Mei dan 9 Mei 2017 di kelas VA dan VB SDN 09 Bandar Buat pada pembelajaran PKn peneliti menemukan permasalahan dalam pembelajaran PKn yaitu pembelajaran berpusat pada guru, di mana guru yang lebih mendominasi pembelajaran dengan menjelaskan dan bertanya. Ketika pembelajaran guru belum maksimal dalam memberikan suatu permasalahan sebagai pemicu terhadap konsep yang akan dipelajari dalam pembelajaran, akibatnya pembelajaran yang dilakukan belum memberikan tantangan akan rasa ingin tahu siswa. Guru juga belum maksimal dalam mengorientasikan siswa pada masalah, belum maksimal dalam mengorganisasi siswa untuk belajar, belum 
maksimal dalam membimbing penyelidikan individual dan kelompok, guru juga belum maksimal dalam mengembangkan dan menyajikan hasil karya dan guru belum maksimal dalam menganalisis dan mengevaluasi proses pemecahan masalah.

Mengatasi masalah tersebut guru harus mampu memberikan pembelajaran inovasi-inovasi dalam pembelajaran PKn agar siswa aktif dalam belajar sehingga masalah siswa dapat diatasi dan tujuan pembelajaran dapat dicapai. Menurut Rusman (2011:238) tujuan model PBLyaitu "Penguasaan isi belajar dari disiplin heuristik dan pengembangan keterampilan pemecahan masalah sekaligus mengembangkan kemampuan siswa untuk secara aktif membangun pengetahuan sendiri”.

Berdasarkan alasan-alasan tersebut maka peneliti ingin membuktikan dengan penelitian eksperimen dengan judul "Pengaruh Model Problem Based Learning (PBL) Terhadap Hasil Belajar Siswa dalam Pembelajaran Pendidikan Kewarganegaraan Kelas V SDN 09 Bandar Buat”.

Tujuan penelitian ini adalah "Melihatpengaruh model Problem Based Learning (PBL) terhadap hasil belajar siswa pada pembelajaran Pendidikan Kewarganegaraan kelas V Sekolah Dasar".

\section{METODE PENELITIAN}

Penelitian inidilaksanakan di SDN 09 Bandar Buat. Penelitian dilakukan di lokasi ini berdasarkan kepada pertimbangan sebagai berikutguru bersedia menerima pembaharuan pembelajaran dengan menggunakan model Problem Based Learning dan belum pernah dilakukan penelitian ekperimen di Sekolah Dasar tersebut.

Subjek dalam penelitian adalah siswa SDN 09 Bandar Buat yang terdaftar pada tahun ajaran 2017/2018. Penelitian ini dilaksanakan pada semester genap tahun ajaran 2017/2018. Atau bertepatan dengan semester delapan pada perkuliahan.

Jenis penelitian ini adalahpenelitianeksperimen.Jenis penelitian yang digunakan yaitu eksperimen semu (quasieksperimental).Suryabrata (2015:92) mengatakan bahwa tujuan penelitian eksperimental-semu adalah untuk memperoleh informasi yang merupakan perkiraan bagi informasi yang dapat diperoleh dengan eksperimen yang sebenarnya dalam keadaan yang tidak memungkinkan untuk mengontrol dan/ataumemanipulasikan semua variabel yang relevan.”. 
Kegiatan penelitian dimulai dari uji coba soal pada sekolah lain yang memiliki akreditasi sama, selanjutnya melakukan belajar baru dilakukan posttest.

Penelitian ini ada variabel yang menjadi perhatian utama yaitu variabel bebas dan variabel terikat. Variabel bebas pada penelitian ini adalah variabel yang kedudukannya memberi pengaruh terhadap vaiabel terikat dengan cara diberi perlakuan pada sampel peneltian yaitu model PBL. Sedangkan variabel terikat adalah variabel yang dipengaruhi oleh variabel bebas dimana variabel terikat pada penelitian ini adalah hasil belajar PKn yang diukur dalam aspek C1, C2 dan C3.

Instrumen penelitian yang digunakan adalah soal tes hasil belajar. Soal tes hasil belajar berupa tes. Tes disusun berdasarkan kisi-kisi pada indikator yang terdapat dalam materi yang dipelajari. Suatu tes dikatakan layak digunakan atau belum maka ada beberapa hal yang perlu dianalisa dari soal-soal tersebut meliputi, validitas item tes hasil belajar, daya pembeda, indeks kesukaran tes, dan realibilitas soal.

Teknik analisis data menggunakan uji t-tes dilakukan dengan bantuan SPSS $\vee 17$ dengan mengikuti langkah-langkah menurut Lestari dan Yudhanegara (2015:256-260). Setelah nilai t-test diketahui, selanjutnya melakukan intepretasi data dengan cara membandingkan nilai $t_{\text {hitung }}$ dengan nilai $t_{\text {table }}$ pada taraf signifikasi $5 \%$. Jika $-t_{\text {hitung }}<-t_{\text {tabel }}$ atau $t_{\text {hitung }}>t_{\text {tabel }}$ maka dapat disimpulkan bahwa pendekatan yang diberikan berpengaruh terhadap hasil belajar peserta didik dan bila $t_{\text {hitung }}>-t_{\text {tabel }}$ atau $t_{\text {hitung }}<t$ tabel

Untuk keperluan pengujian hipotesis, diperlukan rumus hipotesis statistik yaitu pada taraf signifikan $\alpha=0,05(5 \%)$ dengan hipotesis yang akan diuji:

H1 : Adanya pengaruh model PBL terhadap hasil belajarsiswa pada pembelajaran PKn di kelas V SDN 09 Bandar Buat.

Dengan kriteria pengujian :

Jika $\mathrm{t}$ hitung $>\mathrm{t}$ tabel maka Ho ditolak dan $\mathrm{H} 1$ diterima

\section{HASIL PENELITIAN}

\section{A. Data Hasil Penelitian}

\section{Data hasil posttest}

Berdasarkan pengukuran posttest hasil belajar kelompok eksperimen dan kelompok kontrol, terdapat perbedaan perolehan nilai hasil belajar antar kedua kelompok. Nilai rata-rata posttest kelompok kontrol yaitu 80,57 dan kelompok 
eksperimen 86,06. Perbandingan nilai posttest antara kelompok kontrol dan kelompok eksperimen dapat dilihat pada tabel dibawah ini.

\section{Tabel perbandingan nilai posttest kelompok eksperimen dan kelompok kontrol}

\begin{tabular}{|l|l|c|}
\hline No & \multicolumn{1}{|c|}{ kelompok } & Nilai rata-rata \\
\cline { 3 - 3 } & & Posttest \\
\hline 1. & Kontrol & 80,57 \\
\hline 2. & Eksperimen & 86,06 \\
\hline
\end{tabular}

\section{Uji prasyarat analisis}

Uji persyaratan analisis dilakukan untuk melihat kesimpulan tentang data yang diperoleh dari hasil belajar siswa pada kedua kelas sampel. Sebelum melakukan uji hipotesis menggunakan rumus t-test terlebih dahulu dilakukan uji normalitas dan uji homogenitas variansi.

\section{a. Uji normalitas data}

Uji normalitas bertujuan untuk melihat data hasil belajar kedua kelas sampel berdistribusi normal atau tidak. Dalam rancangan penelitian ini, uji normalitas menggunakan statistik inferensial dengan menggunakan uji Shapiro Wilk. Dasar penggunaan uji Shapiro Wilk adalah uji Shapiro Wilk memiliki tingkat keakuratan yang lebih kuat jika banyak data/sampel yang dianalisis kurang dari 50 (Lestari dan Yudhanegara, 2015:243). Uji normalitas dalam rancangan ini menggunakan software SPSS $v$ 17.Taraf signifikansi uji normalitas $(\alpha)$ sebesar $5 \%(0.05)$. Hipotesis uji normalitas pada penelitian ini adalah:

$$
\begin{aligned}
& \mathrm{H}_{0} \quad \text { : Data berdistribusi normal } \\
& \mathrm{H}_{1} \quad \text { : Data tidak berdistibusi normal }
\end{aligned}
$$

Hasil data posttest, uji normalitas kelas kontrol dapat dilihat pada tabel, sebagai berikut: 


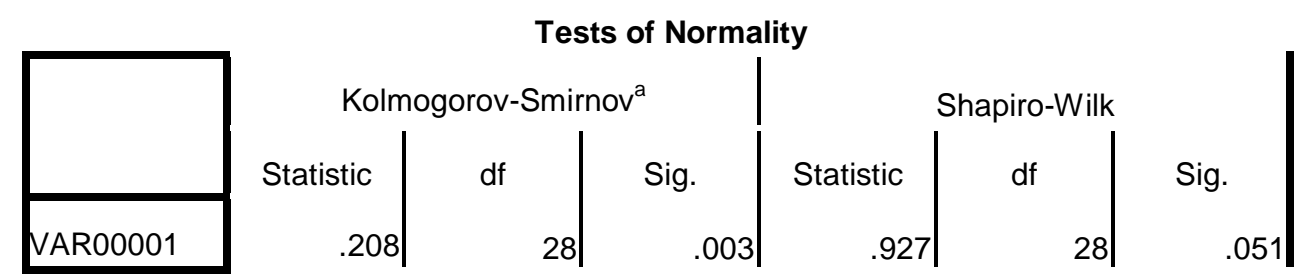

a. Lilliefors Significance Correction

Pada tabel, diperoleh P-Value yang diperoleh sebesar 0.051. Karena nilai P-Value $>\alpha$, maka $\mathrm{H}_{0}$ diterima (tidak cukup bukti/data untuk menolak $\mathrm{H}_{0}$ ). Dengan demikian, dapat disimpulkan bahwa pada taraf kepercayaan 95\%, data posttest di kelas kontrol berdistribusi normal.

Hasil data posttest, uji normalitas kelas eksperimen dapat dilihat pada tabel, sebagai berikut:

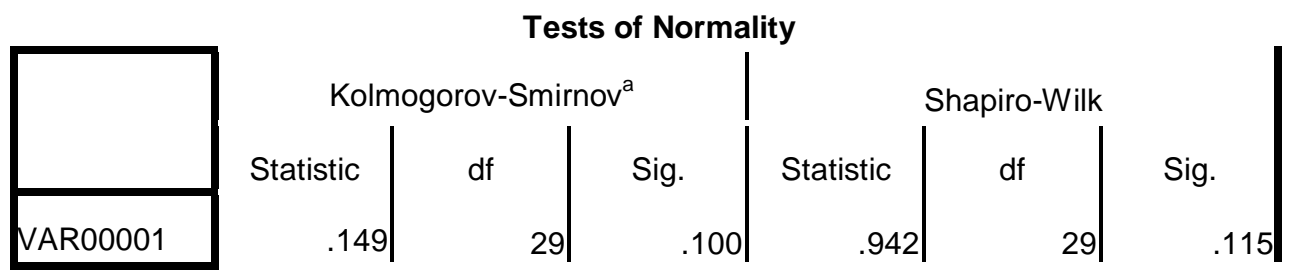

a. Lilliefors Significance Correction

Pada tabel, diperoleh P-Value yang diperoleh sebesar 0.115. Karena nilai P-Value $>\alpha$, maka $\mathrm{H}_{0}$ diterima (tidak cukup bukti/data untuk menolak $\mathrm{H}_{0}$ ). Dengan demikian, dapat disimpulkan bahwa pada taraf kepercayaan 95\%, data posttest di kelas eksperimen berdistribusi normal.

\section{b. Uji homogenitas variansi}

Uji homogenitas variansi bertujuan untuk melihat data hasil tes belajar kelas eksperimen dan kelas kontrol mempunyai variansi yang homogen atau tidak. Dalam rancangan penelitian ini, uji homogenitas menggunakan statistik inferensial dengan menggunakan uji Levene's test. Dasar penggunaan uji Levene's test adalah uji Levene's test biasa digunakan untuk menguji homogenitas variasn dari dua sampel independen. 
(Lestari dan Yudhanegara, 2015:248). Uji homogenitas dalam rancangan ini menggunakan software SPSS $v$ 17.Berdasarkan hasil data postest, uji homogenitaskelas kontrol dan kelas eksperimen dapat dilihat pada tabel sebagai berikut:

Test of Homogeneity of Variances

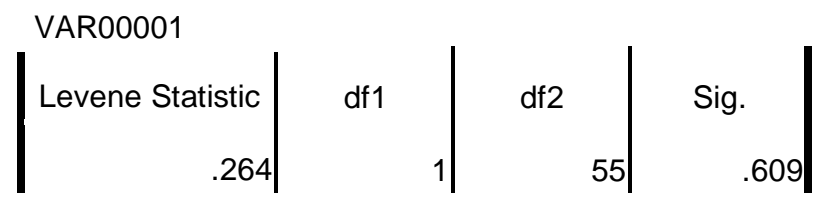

Pada tabel, diperoleh $P$-Value yang diperoleh sebesar 0.609. Karena nilai P-Value $>\alpha$, maka $\mathrm{H}_{0}$ diterima (tidak cukup bukti/data untuk menolak $\mathrm{H}_{0}$ ). Dengan demikian, dapat disimpulkan bahwa pada taraf kepercayaan 95\%, data posttest kedua varians homogen.

\section{Pengujian hipotesis}

Pengujian hipotesis dilakukan uji normalitas dan uji homogenitas variansi diketahui bahwa kedua kelas sampel memiliki data hasil belajar berdistribusi normal dan variansi yang homogen, maka Uji t untuk dua sampel independen dilakukan berdasarkan data hasil posttest di kelas kontrol dan eksperimen. Uji tuntuk dua sampel independen dilakukan dengan bantuan SPSS v.17. Taraf signifikansi uji t $(\alpha)$ sebesar 5\% (0.05). Uji Hipotesis Berdasarkan Data posttest Kelas Kontrol dan Eksperimen. Berdasarkan hasil data posttest di kelas kontrol dan eksperimen, maka hasil uji t dapat dilihat pada tabel di bawah ini: 


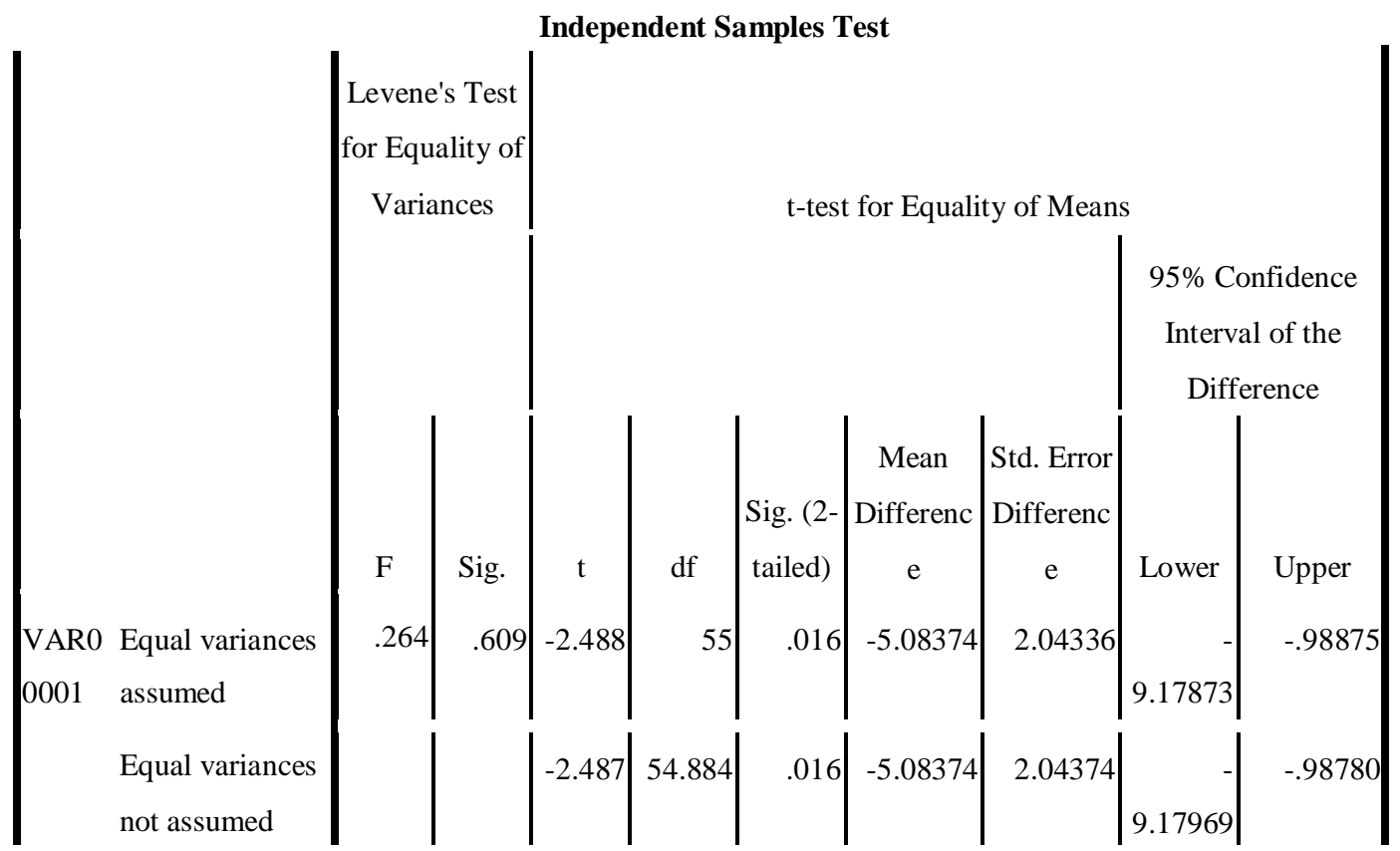

Pada tabel di atas, diperoleh nilai P-Value untuk Levene's test sebesar 0.609, karena nilai tersebut lebih besar dari $\alpha=0.05$, maka varians kedua data homogen. Nilai yang ada pada kolom $t$ merupakan $t_{\text {hitung }}$ yang diperoleh dari hasil perhitungan. Nilai $t$ pada baris pertama, yaitu -2.488 merupakan nilai hasil uji t jika varians kedua data homogen (equal varians assumed), sementara nilai t pada baris kedua, yaitu -2.487 merupakan nilai hasil uji-t yang digunakan jika varians kedua data tidak homogen (equal varians not assumed). Karena hasil uji levene's test menyatakan kedua varians homogen, maka nilai $t_{\text {hitung }}$ yang digunakan adalah yang berdasarkan uji t, yaitu sebesar -2.488 dengan P-Value sebesar 0.016.

Nilai P-Value yang diperoleh lebih kecil dari $\alpha=0.05$, maka $\mathrm{H}_{0}$ ditolak. Artinya pada taraf kepercayaan $95 \%$ berdasarkan data posttest di kelas kontrol dan eksperimen dapat disimpulkan bahwa terdapat pengaruh model PBL terhadap hasil belajar siswa pada pembelajaran PKn di kelas V SDN 09 Bandar Buat.

\section{B. Pembahasan}

Berdasarkan hasil penelitian yang penulis lakukan di kelas V SDN 09 Bandar Buat. aktivitas dan hasil belajar siswa yang diperoleh dari kedua kelas sampel, dapat 
dilihat bahwa terdapat perbedaan hasil belajar siswa dikelas eksperimen yang diajar menggunakan model PBL dengan hasil belajar siswa yang diajar menggunakan pendekatan konvensional. Berikut ini akan dijelaskan gambaran pembelajaran di kelas eksperimen yang diajar menggunakan model PBL dan gambaran pembelajaran di kelas kontrol yang diajar menggunakan pendekatan konvensional.

\section{Pembelajaran di kelas eksperimen}

Pembelajaran yang dilaksanakan di kelas eksperimen yang diajar menggunakan model PBL pada awalnya siswa belum mengenal model PBL, tetapi setelah diberi penjelasan dan langkah-langkah tentang model PBL maka siswa dapat memahaminya. Pada pertemuan pertama, siswa belum terbiasa belajar untuk memecahkan permasalahan, dengan motivasi dan dorongan yang diberikan oleh guru untuk bekerja lebih mandiri dan percaya diri dalam melaksanakan pembelajaran menggunakan model PBL sehingga pada pertemuan kedua hingga pertemuan ketiga siswa memperlihatkan ketertarikan pada proses pembelajaran dengan menggunakan model PBL dengan penguatan dan juga bimbingan yang diberikan oleh guru dalam proses pembelajaran berupa sentuhan, acungan jempol dan kata-kata semangat memberikan banyak manfaat yang diperoleh siswa.

Proses pembelajaran yang dilaksanakan oleh guru menggunakan model PBL dapat mendorong aktivitas pembelajaran siswa sehingga aktivitas belajarcenderung meningkat disetiap pertemuan, hal ini terbukti banyaknya siswa yang bertanya, mengemukakan pendapat kepada guru atau temannya di dalam kerja kelompok dan rasa kebersamaan dalam tim kelompok. Setiap kelompok harus menguasai materi yang diberikan setelah memecahkan permasalahan dengan bantuan berupa panduan diskusi.

Keaktifan belajar siswa dalam proses pembelajaran berdampak pada hasil belajar siswa menjadi lebih baik. Langkah-langkah PBL yang dilaksanakan di kelas eksperimen menurut Hosnan (2014:301) sebagai berikut “(1) orientasi siswa pada masalah (2) mengorganisasikan siswa untuk belajar (3) membimbing penyelidikan individual dan kelompok (4) mengembangkan dan menyajikan hasil karya (5) menganalisis dan mengevaluasi proses pemecahan masalah".

Pembelajaran dengan model PBL pada kelas eksperimen dimulai dengan Pada tahap pertama. Pada tahap ini guru mengorientasikan siswa pada masalah, masalah 
tersebut dapat disajikan dalam bentuk gambar yang diperlihatkan di depan kelas. Setelah siswa melihat gambar guru bertanya jawab dengan siswa mengenai gambar yang diperlihatkan di depan kelas. Sehingga pada tahap ini siswa akan melakukan analisis terhadap fakta sebagai dasar dalam menemukan masalah dan siswa akan berusaha mengeluarkan pendapatnya masing-masing. Pada tahap ini guru memotivasi siswa untuk terlibat dalam aktivitas pemecahan masalah nyata sehingga siswa terlatih untuk mengembangkan kemampuan berfikirnya.

Langkah kedua mengorganisai siswa untuk belajar, guru membentuk siswa menjadi beberapa kelompok. Terlebih dahulu siswa disuruh membaca teks bacaan berupa informasi mengenai yang di pelajari. Pada tahap ini aktifitas guru membantu siswa dalam mengidentifikasi informasi yang dibaca.Langkah ketiga Membimbing penyelidikan individual dan kelompok. Pada tahap ini, setelah siswa membaca teks yang diberikan oleh guru, guru membagikan LDK kepada masing-masing kelompok dan dikerjakan bersama anggota kelompoknya. Guru mengarahkan siswa untuk melakukan penyelidikan terhadap informasi yang diperoleh untuk menjawab LDK yang diberikan. Pada tahap ini menjadikan anak lebih aktif dalam menyelesaikan masalah.

Langkah keempat mengembangkan dan menyajikan hasil karya Setelah masingmasing kelompok selesai mengerjakan LDK. Salah satu perwakilan masing-masing kelompok mempresentasikan hasil karyanya berupa laporan di depan kelas. Kemudian kelompok lain menanggapi hasil laporan kelompok yang tampil. Pada tahap ini siswa dilatih untuk mengeluarkan pendapatnya. Langkah kelima menganalisis dan mengevaluasi proses pemecahan masalah, dengan bimbingan guru siswa merefleksi dan mengevaluasi hasil kerja kelompok kemudian menyimpulkan terhadap pembelajaran yang telah dilaksanakan.

\section{Pembelajaran di kelas kontrol}

Kegiatan pembelajaran menggunakan pembelajaran konvensional menekankan penyampaian informasi secara verbal dan cenderung searah, pendekatan konvensional yang digunakan yaitu dengan metode ceramah. Sesuai pendapat Menurut Majid (2014:194) "Metode ceramah merupakan suatu cara yang digunakan guru dalam mengembangkan proses pembelajaran melalui cara penuturan". Sejalan dengan pendapat Rooijakkers (dalam Boyannese, 2012:2) "pembelajaran konvensional 
merupakan pendekatan pembelajaran satu arah arah yang berpusat pada guru. Dalam praktiknya, guru sebagai sumber informasi utama yang mengambil peranan sentral dalam pembelajaran".

Dengan demikian pembelajaran di kelas kontrol yang diajar menggunakan pendekatan konvensional mengakibatkan siswa menjadi jenuh dan siswa menjadi pasif dalam pembelajaran di kelas karna hanya sedikit siswa yang mengeluarkan pendapatnya. Dalam proses pembelajaran di kelas kontrol terlihat masih ada beberapa siswa yang tidak mengikuti pembelajaran dengan serius dibuktikan dengan adanya siswa yang membuat mainan pesawat-pesawat dari kertas dan berlari-lari di dalam kelas sehingga mengganggu proses pembelajaran yang berlangsung. Hal ini menunjukkan bahwa siswa di kelas kontrol kurang aktif dibandingkan siswa di kelas eksperimen dalam proses pembelajaran, sehingga berdampak pada hasil belajar siswa di kelas kontrol lebih rendah dari hasil belajar siswa di kelas eksperimen.

Terdapat pengaruh model Problem Based Learning (PBL) terhadap hasil belajar siswa pada pembelajaran Pendidikan Kewarganegaraan kelas V SDN 09 Bandar Buat.

Pengujian hipotesis pada penelitian ini adalah melihat terdapat atau tidaknya pengaruh model PBL terhadap hasil belajar siswa pada pembelajaran PKn. Hipotesis mengenai pengaruh model PBL terhadap hasil belajar siswa pada pembelajaran PKn di uji menggunakan statistik paramentrik menggunakan rumus t. Berdasarkan analisa data yang diperoleh setelah penelitian, terdapat pengaruh model PBL terhadap hasil belajar siswa pada pembelajaran PKn yang terlihat pada perbedaan hasil belajar siswa yang diajar menggunakan model PBL dengan hasil belajar siswa yang diajar menggunakan pendekatan konvensional. Hal ini dapat dilihat pada tes akhir siswa yang diberikan kepada kelas eksperimen dan kelas kontrol. Dengan menggunakan model PBL pada kelas eksperimen hasil belajar siswa meningkat. Suprijono (2013:5) menyatakan "Hasil belajar adalah pola-pola perbuatan, nilai-nilai, pengertian-pengertian, sikap-sikap, apresiasi dan keterampilan”.

Bimbingan guru yang mengarah siswa untuk aktif dalam pembelajaran serta mencari penyelesaian terhadap masalah, siswa belajar untuk menyelesaikan tugastugasnya. Sesuai dengan pendapat Sudjana (2009:22) menyatakan "Hasil belajar adalah 
kemampuan-kemampuan yang dimiliki siswa setelah ia menerima pengalaman belajarnya".

Hasil belajar pada kedua kelas dapat dilihat pada tes hasil belajar yang dikerjakan siswa secara individu. Berdasarkan hasil analisa data hasil belajar diperoleh skor maksimal kelas eksperimen adalah 100 dan skor minimal adalah 76,00 sedangkan nilai rata-rata kelas eksperimen adalah 86,06. Skor maksimal kelas kontrol adalah 100 dan skor minimal adalah 68,00 sedangkan nilai rata-rata kelas kontol adalah 80,57. Dengan demikian dapat disimpulkan bahwa terdapat pengaruh model Problem Based Learning (PBL) terhadap hasil belajar siswa pada Pembelajaran Pendidikan Kewarganegaraan kelas V SDN 09 Bandar Buat.

\section{SIMPULAN DAN SARAN}

Berdasarkan hasil penelitian yang telah dikemukakan pada BAB IV dapat disimpulkan bahwa hasil belajar siswa di kelas eksprimen yang diajarkan menggunakan model PBL tergolong sangat tinggi, dengan hasil belajar diperoleh skor maksimal 100 dan skor minimal adalah 76,00 sedangkan nilai rata-rata kelas eksperimen adalah 86,06. Dengan demikian model PBL dapat mempengaruhi hasil belajar siswa di kelas.

Berdasarkan kesimpulan di atas dapat dikemukakan beberapa saran untuk perbaikan hasil pembelajaran, antara lain : bagi guru agar dapat menerapkan model PBL dalam proses pembelajaran PKn di SD, karena penerapan model PBL dapat meningkatkan hasil belajar siswa, penelitian ini tidak terlepas dari kekurangankekurangan. Untuk itu disarankan pada peneliti selanjutnya untuk lebih meneliti aspekaspek lain yang dapat mengantisipasi kendala-kendala yang terjadi selama proses pembelajaran.

\section{DAFTAR RUJUKAN}

Arikunto, Suharsimi. 2009. Dasar-dasar Evaluasi Pendidikan. Jakarta: Bumi Aksara

Daryono. 2011. Pengantar Pendidikan Pancasila dan Kewarganegaraan. Jakarta: PT RINEKA CIPTA

Hosnan, M. 2014. Pendekatan Saintifik dan Kontekstual dalam Pembelajaran Abad 21. Bogor: Ghalia Indonesia 
Lestari, Karunia Eka. 2015. Penelitian Pendidikan Matematika. Bandung: Refika Aditama.

Riyanto, Yatim. 2010. Paradigma Baru Pembelajaran. Jakarta : KENCANA

Rusman. 2011. Model Model Pembelajaran. Jakarta : PT RAJAGRAFINDO

Sani. 2014. Pembelajaran Saintifik Untuk Implementasi Kurikulum 2013. Jakarta : Bumi Aksara PERSADA

Sudjana, Nana. 2009. Penilaian Hasil Proses Belajar Mengajat. Bandung: Remaja Rosdakarya

Suprijono, Agus. 2013. Cooperative Learning Teori dan Aplikasi PAIKEM. Yogyakarta: Pustaka Belajar

Sudjana. 2009. Penilaian Hasil Proses Belajar Mengajar. Bandung : PT Remaja Rosdakarya

Trianto. 2013. Mendesain Model Pembelajaran Inovatif Progresif. Jakarta : KENCANA 
PENGARUH MODEL PBL TERHADAP HASIL BELAJAR SISWA PADA PEMBELAJARAN PENDIDIKAN

KEWARGANEGARAAN KELAS V

SEKOLAH DASAR

ARTIKEL

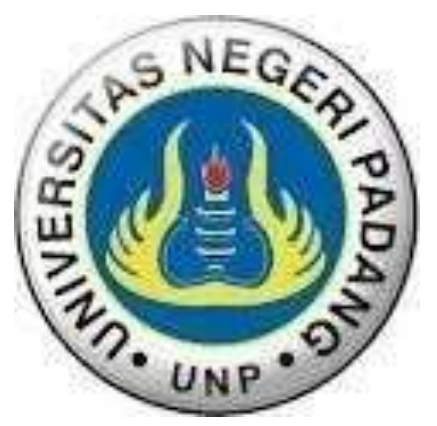

Oleh

ADELA OKTAVIANI

NIM.1304936

PENDIDIKAN GURU SEKOLAH DASAR

FAKULTAS ILMU PENDIDIKAN

UNIVERSITAS NEGERI PADANG

Wisuda Periode 110 Maret 2018 


\title{
PERSETUJUAN PEMBIMBING
}

\author{
PENGARUH MODEL PBL TERHADAP HASIL BELAJAR \\ SISWA PADA PEMBELA.JARAN PENDIDIKAN \\ KEWARGANEGARAAN KELAS V \\ SEKOLAH DASAR
}

\section{ADELA OKTAVIANI}

Artikel ini disusun berdasarkan skripsi yang berjudul, "Pengaruh Model Problem Based Learning (PBL) Terhadap Hasil Belajar Siswa Pada Pembelajaran Pendidikan Kewarganegaraan Kelas V SDN 09 Bandar Buat" untuk persyaratan wisuda periode maret 2018 dan telah direview dan disetujui oleh kedua pembimbing.

Padang, Januari 2018

Pembimbing I

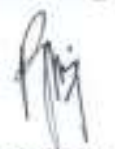

Dra. Reinita, M.Pd

NIP. 196306041988032002

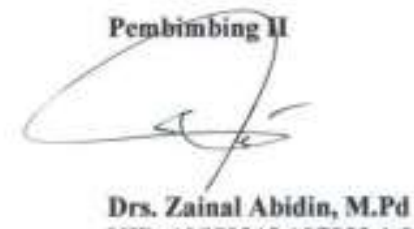

NIP. 195508181979031002 